\title{
ЕКСПРЕСІЯ ЕНДОТЕЛІАЛЬНОГО ФАКТОРА РОСТУ СУДИН У КОРІ ВЕЛИКОГО МОЗКУ ПРИ ПОРУШЕННЯХ КРОВООБІГУ ЗА УМОВ ПОПЕРЕДНЬОЇ СЕНСИБІЛІЗАЦІї МОЗКОВИМ АНТИГЕНОМ ТА ІМУНОКОРЕКЦІї
}

\author{
๑Л. М. Яременко ${ }^{1}$, С. Є. Шепелєв ${ }^{1}$, О. М. Грабовий² \\ Національний медичний університет імені О. О. Богомольця, м. Київ ${ }^{1}$ \\ Національний інститут раку, м. Київ ${ }^{2}$
}

РЕЗЮмЕ. Вступ. Ендотеліальний фактор росту судин (VEGF) є сигнальним протеїном, який стимулює ангіогенез та виконує трофічні функції, у тому числі в нервовій системі. Зазначений фактор росту впливає на процеси розвитку та міграції нервових клітин, їх виживання.

Мета дослідження - оцінити зміни експресії VEGF у корі великих півкуль головного мозку при порушеннях кровообігу за умов попередньої сенсибілізації мозковим антигеном та імунокорекції.

Матеріал і методи. При моделюванні транзиторної ішемії та корекції нейродегенеративних змін імунофаном був проведений експеримент на 135 білих статевозрілих щурах-самцях масою 260-290 г. Були застосовані гістологічні, імуногістохімічний, морфометричний та статистичний методи дослідження.

Результати. Проведені спостереження показали, що сенсибілізація мозковим антигеном очікувано призводить у сенсомоторній корі до виразних нейродегенеративних змін та вірогідного зниження експресії VEGF у нейроцитах. Емболія судин гемомікроциркуляторного русла на фоні попередньої сенсибілізації характеризується посиленням нейродегенеративних та деструктивних змін у корі мозку та більш суттєвим зменшенням експресії VEGF у нейроцитах. При цьому часткове ії відновлення після порушення кровообігу на фоні сенсибілізації відбувається повільніше, ніж тоді, коли остання не проводилася. Це можна розглядати як імунозалежне пригнічення компенсаторно-відновлювальних процесів, індукованих сенсибілізацією. Збільшення кількості гліоцитів, що спостерігалося після ішемічної атаки, супроводжувалося зростанням у них експресії VEGF.

Імунофан вірогідно зменшує виразність нейродегенеративних змін та зниження експресії VEGF, викликаних як порушенням кровообігу в корі мозку, так і сенсибілізацією. Це може бути пов'язано як з прямим впливом імунофану, обумовленим його антиоксидантними властивостями, так і опосередковано, за рахунок відносної активації системи Т-регуляторних клітин, яка є одним із нейропротекторних факторів, що активуються після ішемії.

Висновки. Сенсибілізація мозковим антигеном призводить до виразних нейродегенеративних змін у сенсомоторній корі та зниження експресії VEGF у нейроцитах.

Емболія судин гемомікроциркуляторного русла на фоні попередньої сенсибілізації характеризується посиленням нейродегенеративних та деструктивних змін у корі мозку, виразнішим зменшенням експресії VEGF та уповільненням відновлювальних процесів.

Імунофан вірогідно зменшує виразність нейродегенеративних змін та зниження експресії VEGF, викликаних як порушенням кровообігу в корі мозку, так і сенсибілізацією.

КЛючОВI СЛОВА: ішемія мозку; сенсибілізація; VEGF; імунофан.

Вступ. Ендотеліальний фактору росту судин (VEGF - Vascular endothelial growth factor) $\epsilon$ сигнальним протеїном, який стимулює ангіогенез та виконує трофічні функції, у тому числі в нервовій системі [1-3]. Зазначений фактор росту впливає на процеси розвитку та міграції нервових клітин, їх виживання $[4,5]$. Зміни вмісту VEGF у сироватці крові були виявлені при цілому ряді патологічних станів, у тому числі спостерігалося його зменшення при інсультах [6]. Введення VEGF при інсульті приводить до покращення неврологічних показників та суттєвого зменшення об'єму інфаркту $[5,7]$.

3 позицій корекції імуносупресії та нейрозапалення, що супроводжує ішемічне ураження мозку $[8,9]$, привертає увагу синтетичне похідне тимопоетину - імунофан (аргініл-альфа-аспартил-лізил-валіл-тирозил-аргінін), який має імунорегулювальні властивості, блокує вільнорадикальні процеси пе- рекисного окиснення [10], запобігає пошкодженню лімфоцитів та гранулоцитів [11]. Крім імунних ефектів, імунофан підвищує антиоксидантну резистентність шляхом стимуляції синтезу церулоплазміну і лактоферину та активності каталази, знижує продукцію медіаторів запалення $[10,11]$. Показані нейропротекторні властивості цього поліпептиду $[8,12]$

Мета роботи - оцінити зміни експресії епітеліального фактора росту судин (VEGF) у корі великих півкуль головного мозку при порушеннях кровообігу за умов попередньої сенсибілізації мозковим антигеном та імунокорекції.

Матеріал і методи дослідження. Дослідження виконане на 135 самцях білих статевозрілих щурів лінії Вістар вагою 260-290 г, яких утримували у віварії на стандартному раціоні, по 5 тварин у клітці, з вільним доступом до харчування і води та 
Огляди літератури, оригінальні дослідження, погляд на проблему, ювілеї

постійним світло-затемненим режимом згідно $з$ «Принципами ухода за лабораторными животными». Досліди проводили згідно з положеннями міжнародних принципів гуманного поводження 3 тваринами, викладеними в «Guide for the Care and Use of Laboratory Animals» (NIH publ. No. 93 23, revised 1985). У роботі використовували самців, оскільки рівень естрогенів впливає на перебіг ішемічного ушкодження головного мозку [13]. Тварин було рандомізовано поділено на 6 груп. Щури групи К (інтактний контроль; n=10) не зазнавали жодних втручань. Тварини всіх інших груп за 12 діб до оперативного втручання були сенсибілізовані 20 \% водно-сольовим екстрактом (антигеном) гомологічної тканини мозку, отриманого за загальноприйнятою методикою [14], з вмістом білка 0,33-0,5 мг/мл за Лоурі. Щурам підшкірно вводили: в 1 день - 0,5 мл; в 2 день - 1 мл; в 3 день - 1,5 мл екстракту [15]. При цьому тварини групи Кс (контроль, сенсибілізовані; n=25) не зазнавали жодних інших втручань. Тваринам групи ПОс (псевдооперовані, сенсибілізовані; $\mathrm{n=25)}$ здійснювали оперативний доступ до лівої загальної сонної артерії та її мобілізацію, після чого рану зашивали. Щурам групи ПСАс (перев'язка сонної артерії, сенсибілізовані; n=25) здійснювали аналогічний доступ до лівої загальної сонної артерії та її мобілізацію, після чого в зазначену артерію вводили 0,2 мл фізіологічного розчину та накладали лігатуру. Тваринам груп MEAc (з мікроемболізацією басейну сонної артерії, сенсибілізовані; n=25) та MEAc+i (MEAc+імунофан; $\mathrm{n}=25$ ) моделювали гостре порушення мозкового кровообігу шляхом введення у ліву загальну сонну артерію 0,2 мл розчину, що містив 20 мл відмитих ізольованих адипоцитів, 2,8 мл $10 \% \mathrm{CaCl}_{2}, 10$ г твіну та 0,9 \% NaCl до загального об'єму 100 мл [16], після чого на артерію накладали лігатуру. При цьому щури МЕАс+і отримували підшкірно по 0,5 мкг імунофану (НВП «Бионокс», Росія) на 1-10, 21-23, 30-32, 50-51 дні експерименту. Тваринам груп ПОс та ПСАс підшкірно водили фізіологічний розчин за аналогічною схемою. Всі оперативні втручання було виконано з використанням тіопенталового наркозу (50 мг/кг).

Головний мозок для досліджень отримували від тварин через 1, 3, 10, 30 та 90 діб після оперативного втручання, тобто, відповідно, через 13, 15, 22, 42 та 102 доби після сенсибілізації мозковим антигеном, після надмірного введення тваринам тіопенталу натрію (200 мг/кг). Протягом до 1 хв проводили розтин черепа, виймали мозок, який фронтально розрізали на три частини і середню поміщали у 10 \% забуферений формалін $\left(\mathrm{pH} 7,4,4^{\circ} \mathrm{C}\right)$ на 24 години. Матеріал ущільнювали в парафін і виготовляли зрізи товщиною 4 мкм, які забарвлювали азур II-еозином.
Імуногістохімічну (IГX) реакцію для виявлення VEGF проводили у відповідності з протоколом виробника з первинним антитілом до VEGF (Vascular Endothelial Growth Factor Ab-1 (RB-222) Polyclonal (імуноген VEGF165) Human, Mouse \& Rat. (Lab Vision, USA)) у розведенні 1:200. Для візуалізації продуктів ІГX реакції використовували систему детекції EnVisionTM FLEX, (Dako, Denmark). Кожний другий зріз дофарбовували гематоксиліном Gill. У якості позитивного контрою використовували зразки мозку щурів з визначеною позитивною реактивністю, а для негативного - проводили процедуру без застосування первинних антитіл.

Гістологічні препарати вивчали та фотографували за допомогою мікроскопа Olympus BX51, цифрової камери Olympus C4040ZOOM, комп'ютера із програмним забезпеченням Olympus DP-Soft 3.2. за стандартизованих умов. На 7 мікрофото (x400, 1280x960 пікселів RGB) в 35 пірамідних нейронах визначали інтенсивність експресії VEGF денсіометричним методом за допомогою системи аналізу зображення ImageJ 1,46: їх трансформували у 8-бітні та вимірювали оптичну щільність симетричних ділянок гангліонарного шару кори великих півкуль (лівої та правої). Для оцінки статистичної вірогідності відмінностей середніх значень експресії VEGF між групами, а також між ураженою та контралатеральною півкулями мозку, використовували t-критерій Стьюдента. Міжгрупові відмінності вважали вірогідними при $\mathrm{P}<0,05$.

Результати й обговорення. У щурів контрольної групи (умовно інтактних) сенсомоторна кора півкуль мозку мала звичайну будову і містила у гангліонарному шарі великі пірамідні нейроцити та невелику кількість гліоцитів. Імуногістохімічно виявлялася, як правило, висока експресія VEGF у цитоплазмі нейронів. Порівняно часто при цьому безпосередньо навколо ядра вона була виражена менше, і ядро виглядало оточеним світлим обідком. Іноді помірне накопичення хромогену спостерігалося в аксонах. Невисока експресія VEGF спостерігалася й у нейропілі у вигляді дрібнозернистої субстанції. У цитоплазмі частини гліальних клітин також виявлялася невисока експресія цього фактора (рис. 1). Вірогідних відмінностей експресії VEGF у правій та лівій півкулях виявлено не було.

У тварин групи Кс через 12, 15 і 22 доби після сенсибілізації в корі великих півкуль виявлявся помірний периваскулярний набряк. Нейрони часто мали деформовані контури та глибчасту гіперконденсовану хроматофільну субстанцію. Іноді спостерігалися явища хроматолізу. Виявлялися поодинокі дегенеруючі гіперхромні та, рідше, некротично змінені нейрони. Іноді виявлялися осередки дрібногубчастої дегенерації. 3 часом ці явища ставали менш виразними. Водночас спо- 
Огляди літератури, оригінальні дослідження, погляд на проблему, ювілеї

стерігалося збільшення кількості гліоцитів у корі мозку, які наприкінці досліду (102 доба після сенсибілізації) могли утворювати невеличкі скупчення. Відбувалося статистично вірогідне зниження рівня експресії VEGF у всі терміни спостереження (рис. 1). Статистично вірогідних відмінностей рівня експресії VEGF у правій та лівій півкулях тварин цієї групи виявлено не було.
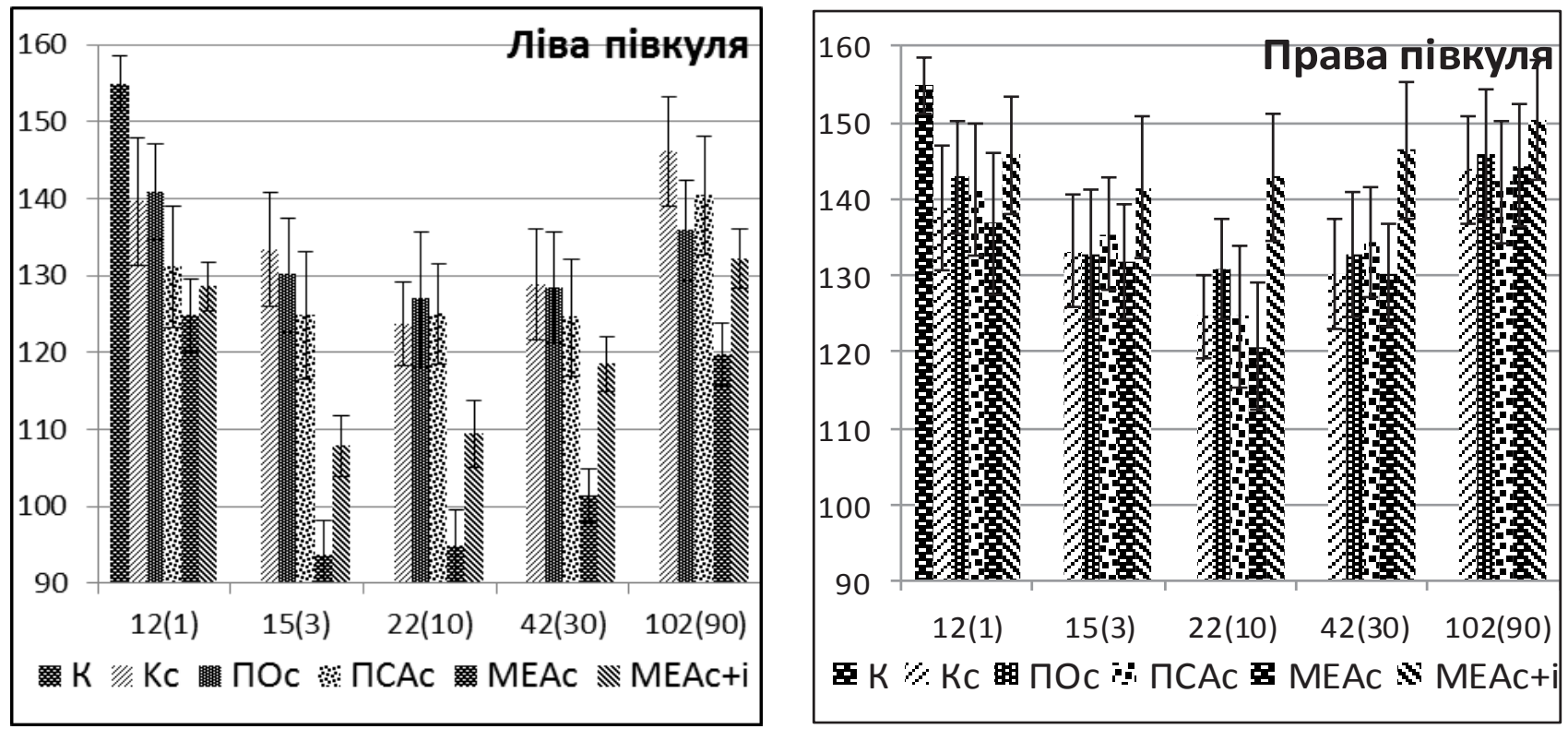

К - інтактний контроль; Кс - контроль, сенсибілізовані; ПОс - псевдооперовані, сенсибілізовані; ПСАс - перев'язування лівої загальної сонної артерії, сенсибілізовані; МЕАс - мікроемболія адипоцитами судин у басейні лівої загальної сонної артерії, сенсибілізовані; МЕАс - тварини МЕАс+і, які отримували імунофан, 12 (1) - 102 (90) - доби після введення мозкового антигену (перша цифра) та моделювання порушення кровотоку (друга цифра).

Рис. 1. Рівень експресії VEGF (ум. од.) у цитоплазмі нейронів кори лівої та правої великих півкуль головного мозку щурів за умов сенсибілізації мозковим антигеном, порушень кровообігу та імунокорекції.

У правій півкулі, контрлатеральній щодо втручань, які проводилися, у тварин груп ПОс, ПСАс та МЕАс візуально не виявлялися відмінності від картини, що спостерігалася у тварин групи Кс. Рівні експресії VEGF у нейронах сенсомоторної кори цієї півкулі у тварин зазначених дослідних груп також вірогідно не відрізнялися від показників групи Кс (див. рис. 1).

У щурів групи ПОс загальна картина стану кори великих півкуль з боку ураження практично не відрізнялася від тієї, що спостерігалася в групі Кс, так само, як і рівень експресії VEGF (див. рис. 1). У тварин групи ПСАс відмічалося незначне посилення, порівняно з групами Кс та ПОс, виразності нейродегенеративних явищ.

У корі ураженої півкулі щурів групи МЕАс спостерігалося значне посилення, порівняно з вищеописаними дослідними групами, нейродегенеративних явищ. Насамперед це стосувалося судинної реакції та дегенеративних/деструктивних змін нейроцитів кори мозку. Частина мікросудин виявлялася різко розширеною, що супроводжувалося периваскулярним набряком. Ці зміни були найбільш виразні на 1, 3, 10 доби після відтворення мікроемболії, а у подальшому поступово змен- шувалися. Часто спостерігалися явища дрібнокомірчастої, навіть пилоподібної, дегенерації, що поширювалася на значні площі кори. На цьому фоні визначалися осередки крупнокомірчастих змін. Іноді виявлялися інфаркти, на місці яких у подальшому (10 доба після втручання) формувалися гліальні рубці або псевдокісти. Дегенеративні та некротичні зміни нейроцитів були розповсюдженими. Найвиразнішими вони були через 1 i 3 доби після втручання. Відносно частіше, порівняно з тваринами, що не зазнавали сенсибілізації [17], вони продовжували виявлятися у більш пізні строки, й навіть через 90 діб після моделювання мікроемболії. Нейродегенеративні зміни в сенсомоторній корі супроводжувалися поступовим зростанням питомої кількості гліоцитів.

ІГХ дослідження виявило статистично вірогідно менший рівень експресії VEGF у лівій півкулі, порівняно з групою Кс, на всіх термінах спостереження та, починаючи з 3 доби після втручання, порівняно з контрлатеральною півкулею (див. рис. 1). Збільшення кількості гліоцитів у сенсомоторній корі, що спостерігалося після ішемічного ушкодження, супроводжувалося зростанням серед них частки таких, які виявляли помірну експресію 
Огляди літератури, оригінальні дослідження, погляд на проблему, ювілеї

VEGF. Особливо помітно це було в гліальних рубцях та, меншою мірою, в стінках псевдокіст.

За умов дії імунофану при емболії мікросудин лівої півкулі (група MEAC+i) у сенсомоторній корі щурів спостерігалося зменшення як виразності нейродегенеративних змін та гліальної реакції, так і пригнічення експресії VEGF в нейроцитах, порівняно з групою МЕАс (відмінності вірогідні, починаючи з 3 доби після оперативного втручання) (див. рис. 1). Разом з тим, гліоцити частіше, ніж в групі МЕАс, демонстрували виразну присутність VEGF. У правій півкулі (контрлатеральній) під впливом імунофану спостерігався більш ранній початок відновлення експресії VEGF у нейронах, що проявлялося у відсутності вірогідних відмінностей з інтактним контролем, починаючи з 30 доби після втручання (див. рис. 1).

Проведені спостереження показали, що сенсибілізація мозковим антигеном очікувано [16] призводить у сенсомоторній корі до виразних нейродегенеративних змін та вірогідного зниження експресії VEGF у нейроцитах. Емболія судин гемомікроциркуляторного русла на фоні попередньої сенсибілізації характеризується посиленням нейродегенеративних та деструктивних змін у корі мозку та більш суттєвим зменшенням експресії VEGF у нейроцитах. При цьому часткове її відновлення після порушення кровообігу на фоні сенсибілізації відбувається повільніше, ніж тоді, коли остання не проводилася [17]. Це можна розглядати як імунозалежне пригнічення компенсаторновідновлювальних процесів, індукованих сенсибілізацією. Збільшення кількості гліоцитів, що спостерігалося після ішемічної атаки, супроводжувалося зростанням у них експресії VEGF. Дисциркуляторні зміни, що виникали при травмі сонної артерії (група ПОс) чи ії перев'язуванні (група ПСАС), призводили до мінімальних змін у корі мозку. Отже, основним патогенетичним фактором виявлених змін $\epsilon$ транзиторна ішемія. Слід зазначити, що, за даними ряду авторів, при оклюзії середньої мозкової артерії спостерігалося зростання експресії VEGF у мозку, особливо впродовж першої доби після ушко- дження [18-20], що пов'язувалося з мікроглією [18] або ендотелієм судин [20]. Суттєве збільшення рівня експресії VEGF було виявлено і в зоні ішемічного інсульту в зразках головного мозку людини [21]. Але застосована нами модель, ґрунтуючись на короткотривалій емболізації гемомікроциркуляторного русла адипоцитами, відтворює транзиторні порушення мозкового кровообігу [16]. Відповідно, відмінності реакцій при застосуванні мікроемболії кровоносних судин ізольованими адипоцитами [17] та оклюзії середньої мозкової артерії [18-20], можуть бути пов'язані з характером та динамікою порушень мозкового кровотоку та реперфузії.

Імунофан вірогідно зменшує виразність нейродегенеративних змін та експресії VEGF, викликаних як порушенням кровообігу в корі мозку, так і сенсибілізацією. Це може бути пов'язано як 3 прямим впливом імунофану, обумовленим його антиоксидантними властивостями [10], так і 3 опосередкованим, за рахунок відносної активації системи Т-регуляторних клітин $[8,10,11]$, яка виступає в якості одного з нейропротекторних факторів, що активуються після ішемії $[22,23]$.

Висновки. Сенсибілізація мозковим антигеном призводить у сенсомоторній корі до виразних нейродегенеративних змін та зниження експресії VEGF у нейроцитах.

Емболія судин гемомікроциркуляторного русла на фоні попередньої сенсибілізації характеризується посиленням нейродегенеративних та деструктивних змін у корі мозку, виразнішим зменшенням експресії VEGF та уповільненням відновлювальних процесів.

Імунофан вірогідно зменшує виразність нейродегенеративних змін та зниження експресії VEGF, викликаних як порушенням кровообігу в корі мозку, так і сенсибілізацією.

Перспективи подальших досліджень полягають у поглибленні уявлень про морфофункціональні зміни в мозку при порушеннях кровообігу та розробці критеріїв оцінки ступеня тяжкості ішемічного ураження.

\section{ЛITЕРАТУРА}

1. Rosenstein J. M. VEGF in the nervous system / J. M. Rosenstein, J. M. Krum, C. Ruhrberg // Organogenesis. -2010 - No. 6 (2). - P. 107-114.

2. Licht T. Delineating multiple functions of VEGF-A in the adult brain / T. Licht, E. Keshet // Cellular and Molecular Life Sciences. - 2013. - No. 70 (10). - P. 1727-1737.

3. Effects of vascular endothelial growth factor in ischemic stroke / Y. Ma, A. Zechariah, Y. Qu, D. M. Hermann // J. Neurosci. Res. - 2012. - No. 90 (10). - P. 1873-1882.

4. VEGF is required for dendritogenesis of newly born olfactory bulb interneurons / T. Licht, R. Eavri, I. Goshen [et al.] // Development. - 2010. - No. 137 (2). - P. 261-271. 
Огляди літератури, оригінальні дослідження, погляд на проблему, ювілеї

5. Intraventricular vascular endothelial growth factor antibody increases infarct volume following transient cerebral ischemia / W. L. Bao, S. D. Lu, H. Wang, F. Y. Sun // Acta Pharmacol. Sin. - 1999. - № 20 (4). - P. 313-318.

6. Mackenzie F. Diverse roles for VEGF-A in the nervous system / F. Mackenzie, C. Ruhrberg // Development. 2012. - No. 20. - P. 1371-1380.

7. Coupling of Neurogenesis and angiogenesis after ischemic stroke / L. Ruan, B. Wang, Q. Zhu Ge, K. Jin // Brain Res. - 2015. - No. 1623. - P. 166-173.

8. Яременко Л. М. Стан популяції лімфоцитів при моделюванні порушень кровообігу у лівій півкулі головного мозку у щурів та його корекція / Л. М. Яременко, О. М. Грабовий // Імунологія та алергологія. - 2009. № 1. - С. 40-44.

9. Грабовий О. М. Стан кори півкуль головного мозку при моделюванні порушень кровообігу та при корекції супутніх змін імунної системи у щурів / О. М. Грабовий, Л. М. Яременко // Науковий вісник Національного медичного університету імені О. О. Богомольця. - 2009. № 4. - C. 28-33.

10. Караулов А. В. Молекулярно-биологическое обоснование применения имунофана в клинической практике / А. В. Караулов // Лечащий врач. - 2000. № 4. - C. 46-47

11. Лебедев В. В. Гидрофильный гексапептид иммунофан - гиперактивный регулятор транспортных белков множественной лекарственной устойчивости / В. В. Лебедев, С. А. Новиков // Бюллетень экспериментальной биологии и медицины. - 2006. - Т. 142. № 12. С. 649-651.

12. Белозерцев Ю. А. Исследование нейропротекторного и ноотропного действия препаратов при патологии ЦНС / Ю. А. Белозерцев, С.В.Юнцев // Забайкальский медицинский вестник. - 2008. - № 2. - С. 42-45.

13. Hurn P. D. Estrogen as a neuroprotectant in stroke / P. D. Hurn, I. M. Macrae // J. Cerebral Blood Flow \& Metabolism. - 2000. - No. 20. - P. 631-652.

\section{REFERENCES}

1. Rosenstein, J.M., Krum, J.M., \& Ruhrberg, C. (2010). VEGF in the nervous system. Organogenesis 6 (2), 107-114.

2. Licht, T., \& Keshet, E. (2013). Delineating multiple functions of VEGF-A in the adult brain. Cellular and Molecular Life Sciences, 70 (10), 1727-1737.

3. Ma, Y., Zechariah, A., Qu, Y., \& Hermann, D.M. (2012). Effects of vascular endothelial growth factor in ischemic stroke. J. Neurosci. Res., 90 (10), 1873-1882.

4. Licht, T., Eavri, R., Goshen, I., Shlomai, Y., Mizrahi, A., \& Keshet, E. (2010). VEGF is required for dendritogenesis of newly born olfactory bulb interneurons. Development, 137 (2), 261-271.

5. Bao, W.L., Lu, S.D., Wang, H., \& Sun, F.Y. (1999). Intraventricular vascular endothelial growth factor antibody increases infarct volume following transient cerebral ischemia. Acta Pharmacol. Sin., 20 (4), 313- 318.

6. Mackenzie, F., Ruhrberg, C. (2012). Diverse roles for VEGF-A in the nervous system. Development, 20, 1371-1380.

7. Ruan, L., Wang, B., Zhu, Ge Q., \& Jin, K. (2015). Coupling of neurogenesis and angiogenesis after ischemic
14. Руководство по иммунологии / под ред. О. Е. Вязова, Ш. Х. Ходжаева. - М. : Медицина, 1973. - 392 с.

15. Ганнушкина И. В. Иммунологические аспекты травмы и сосудистых поражений мозга / И. В. Ганнушкина. - М. : Медицина, 1974. - 271 с.

16. Пат. 36843 Україна. Спосіб моделювання комбінованого судинно-імунного пошкодження мозку (О. М. Грабовий, Л. М. Яременко). Опубл. 10.11.2008, Бюл. № 21.

17. Yaremenko L. M. Expression of vascular endothelial growth factor in the rat cerebral cortex after blood supply disturbances and immunocorrection of their consequences / L. M. Yaremenko, O. O. Grabovyi, O. M. Grabovyi // Neurophysiology. - 2016. - No. 48. - P. 354-359.

18. Cell type specific upregulation of vascular endothelial growth factor in an MCA-occlusion model of cerebral infarct / K. H. Plate, H. Beck, S. Danner [et al.] // J. Neuropathol. Exp Neurol. - 1999. - No. 58 (6). - P. 654-666.

19. Vascular endothelial growth factor and its receptor, KDR, in human brain tissue after ischemic stroke / R. Issa, J. Krupinski, T. Bujny [et al.] // Lab. Invest. - 1999. No. 79 (4). - P.417-425.

20. Vascular endothelial growth factor expression and angiogenesis induced by chronic cerebral hypoperfusion in rat brain / J. Hai, S. T. Li, Q. Lin [et al.] // Neurosurgery. - 2003. - No. 53 (4). - P. 963-970.

21. Mărgăritescu O. VEGF expression in human brain tissue after acute ischemic stroke / O. Mărgăritescu, D. Pirici, C. Mărgăritescu // Rom. J. Morphol. Embryol. - 2010. No. 53 (4). - P. 1283-1292.

22. Liesz A. Regulatory T cells are key cerebroprotective immunomodulators in acute experimental stroke / A. Liesz, E. Suri-Payer, C. Veltkamp // Nature Medicine. - 2009. No. 15. - P. 192-199.

23. Walsh J. T. Regulatory T cells in central nervous system injury: a double-edged sword / J. T. Walsh, J. Zheng, I. Smirnov // J. Immunol. - 2014. - No. 193 (10). - P. 50135022.

stroke. Brain Res., 1623, 166- 173. doi:10.1016/j.brainres.2015.02.042.

8. Yaremenko, L.M., \& Hrabovyi, O.M. (2009). Stan populiatsii limfotsytiv pry modeliuvanni porushen krovoobihu u livii pivkuli holovnoho mozku u shchuriv ta yoho korektsiia [State of the population of lymphocytes in the modeling of circulatory disorders in the left hemisphere of the brain in rats and its correction]. Imunolohiia ta alerholohiia-Immunology and Allergology, (1), 40- 44 [in Ukrainian].

9. Hrabovyi, O.M., \& Yaremenko L.M., (2009). Stan kory pivkul holovnoho mozku pry modeliuvanni porushen krovoobihu ta pry korektsii suputnikh zmin imunnoi systemy u shchuriv [State of the cerebral hemispheres in the modeling of circulatory disorders and in the correction of concomitant changes in the immune system in rats]. Naukovyi visnyk Natsionalnoho medychnoho universytetu imeni 0.O. Bohomoltsia - Scientific Bulletin of the National Medical University named after O.O. Bohomolets (4), 28-33 [in Ukrainian].

10. Karaulov, A.V., (2000). Molekulyarno-biologicheskoe obosnovanie primeneniya imunofana $v$ klinicheskoy 
Огляди літератури, оригінальні дослідження, погляд на проблему, ювілеї

praktike [Molecular-biological substantiation of the use of imunofan in clinical practice]. Lechashchiy vrach - Attending Physician, (4), 46-47 [in Russian].

11. Lebedev, V.V., \& Novikov, S.A. (2006). Gidrofilnyy geksapeptid imunofan - giperaktivnyy regulyator transportnykh belkov mnozhestvennoy lekarstvennoy ustoychivosti [Hydrophilic hexapeptide imunofan - hyperactive regulator of transport proteins of multiple drug resistance]. Byulleten eksperimentalnoy biologii i meditsyny Bulletin of Experimental Biology and Medicine, 142 (12), 649-651 [in Russian].

12. Belozertsev, Yu.A., \& Yuntsev, S.V. (2008). Issledovanie neyroprotektornogo i nootropnogo deystviya preparatov pri patologii TsNS [Study of neuroprotective and nootropic action of drugs in the pathology of the central nervous system]. Zabaykalskiy meditsinskiy vestnik - Transbaikal Medical Gazette, (2), 42-45 [in Russian].

13. Hurn, P.D., \& Macrae, I.M. (2000). Estrogen as a neuroprotectant in stroke. J. Cerebral Blood Flow \& Metabolism 20, 631-652.

14. Vyazova, O.E., \& Khodzhayeva, Sh.Kh. (Eds.). (1973). Rukovodstvo po immunologii [Guide on immunology]. Moscow: Meditsina [in Russian].

15. Gannushkina, I.V. (1974). Immunologicheskie aspekty travmy i sosudistykh porazheniy mozga [Immunological aspects of trauma and vascular lesions of the brain]. Moscow: Meditsina [in Russian].

16. Hrabovyi, O.M., \& Yaremenko, L.M. (2008). Method of modeling of combined vascular-immune brain damage. Ukraine Pat. 36843 [in Ukrainian].
17. Yaremenko, L.M., Grabovyi, O.O. \& Grabovyi, O.M. (2016). Expression of vascular endothelial growth factor in the rat cerebral cortex after blood supply disturbances and immunocorrection of their consequences. Neurophysiology, 48, 354-359. doi:10.1007/s11062-017-9609-y

18. Plate, K.H., Beck, H., Danner, S., Allegrini, P.R., \& Wiessner, C. (1999). Cell type specific upregulation of vascular endothelial growth factor in an MCA-occlusion model of cerebral infarct. J. Neuropathol. Exp. Neurol. 58 (6), 654-666.

19. Issa, R., Krupinski, J., Bujny, T., Kumar, S., Kaluza, J., \& Kumar, P., (1999). Vascular endothelial growth factor and its receptor, KDR, in human brain tissue after ischemic stroke. Lab. Invest., 79 (4), 417-425.

20. Hai, J., Li, S.T., Lin, Q., Pan, Q.G., Gao, F., \& Ding, M.X. (2003). Vascular endothelial growth factor expression and angiogenesis induced by chronic cerebral hypoperfusion in rat brain. Neurosurgery, 53 (4), 963-970; discussion 970-972.

21. Mărgăritescu, O., Pirici, D., \& Mărgăritescu, C. (2010). VEGF expression in human brain tissue after acute ischemic stroke. Rom. J. Morphol. Embryol., 53 (4), 12831292.

22. Liesz, A., Suri-Payer, E., \& Veltkamp, C. (2009). Regulatory $T$ cells are key cerebroprotective immunomodulators in acute experimental stroke. Nature Medicine, 15, 192-199.

23. Walsh, J.T., Zheng, J., \& Smirnov, I. (2014). Regulatory $T$ cells in central nervous system injury: a doubleedged sword. J. Immunol., 193 (10), 5013-5022.

\title{
ЭКСПРЕССИЯ ЭНДОТЕЛИАЛЬНОГО ФАКТОРА РОСТА СОСУДОВ В КОРЕ БОЛЬШОГО МОЗГА ПРИ НАРУШЕНИЯХ КРОВООБРАЩЕНИЯ В УСЛОВИЯХ ПРЕДВАРИТЕЛЬНОЙ СЕНСИБИЛИЗАЦИИ МОЗГОВЫМ АНТИГЕНОМ И ИММУНОКОРРЕКЦИИ
}

\author{
○Л. М. Яременко', С. Е. Шепелев ${ }^{1}$, А. Н. Грабовой²
}

Национальный медицинский университет имени А. А. Богомольца, г. Киев Национальный институт рака, г. Киев

РЕЗЮМЕ. Введение. Эндотелиальный фактор роста сосудов (VEGF) является сигнальным протеином, который стимулирует ангиогенез и выполняет трофические функции, в том числе в нервной системе. Указанный фактор роста влияет на процессы развития и миграции нервных клеток, их выживание.

Цель исследования - оценить изменения экспрессии VEGF в коре больших полушарий головного мозга при нарушениях кровообращения в условиях предварительной сенсибилизации мозговым антигеном и иммунокоррекции.

Материал и методы. При моделировании транзиторной ишемии и коррекции нейродегенеративных изменений иммунофаном был проведен эксперимент на 135 белых половозрелых крысах-самцах массой 260-290 г. Были применены гистологические, иммуногистохимический, морфометрический и статистический методы исследования.

Результаты. Проведенные наблюдения показали, что сенсибилизация мозговым антигеном приводит к выразительным нейродегенеративным изменениям в сенсомоторной коре и достоверному снижению экспрессии VEGF в нейронах. Эмболия сосудов гемомикроциркуляторного русла на фоне предшествующей сенсибилизации характеризуется усилением нейродегенеративных и деструктивных изменений в коре головного мозга и более существенным уменьшением экспрессии VEGF в нейроцитах. При этом частичное восстановление после нарушения кровообращения на фоне сенсибилизации происходит медленнее, чем тогда, когда последняя не проводилась. Это можно рассматривать как иммунозависимое подавление компенсаторно-восстановительных процессов, индуцированных сенсибилизацией. Увеличение количества глиоцитов, наблюдавшееся после ишемической атаки, сопровождалось ростом в них экспрессии VEGF. 
Огляди літератури, оригінальні дослідження, погляд на проблему, ювілеї

Иммунофан достоверно уменьшает выраженность нейродегенеративных изменений и снижение экспрессии VEGF, вызванных как нарушением кровообращения в коре мозга, так и сенсибилизацией. Это может быть связано как с прямым влиянием иммунофана, обусловленным его антиоксидантными свойствами, так и опосредованно, за счет относительной активации Т-регуляторных клеток, которые выступают в качестве одного из нейропротекторных факторов, активирующихся после ишемии.

Выводы. Сенсибилизация мозговым антигеном приводит к выразительным нейродегенеративным изменениям в сенсомоторной коре и снижению экспрессии VEGF в нейроцитах.

Эмболия сосудов головного мозга на фоне предшествующей сенсибилизации характеризуется усилением нейродегенеративных и деструктивных изменений, выразительным уменьшением экспрессии VEGF и замедлением восстановительных процессов в коре головного мозга.

Иммунофан достоверно уменьшает выраженность нейродегенеративных изменений и снижение экспрессии VEGF, вызванных как нарушением кровообращения в коре мозга, так и сенсибилизацией.

КЛЮЧЕВЫЕ СЛОВА: ишемия мозга; сенсибилизация; VEGF; иммунофан.

\title{
EXPRESSION OF THE VASCULAR ENDOTHELIAL GROWTH FACTOR IN THE CEREBRAL CORTEX AT DISTURBANCES OF BLOOD CIRCULATION UNDER CONDITIONS OF PRELIMINARY SENSITIZATION BY BRAIN ANTIGEN AND IMMUNOCORRECTION
}

\author{
@L. M. Yaremenko', S. E. Shepelev ${ }^{1}$, A. N. Grabovoy ${ }^{2}$ \\ O. Bohomolets National Medical University, Kyiv' \\ Ukranian National Cancer Institute, Kyiv²
}

SUMMARY. Introduction. The vascular endothelial growth factor (VEGF) is a signaling protein that stimulates angiogenesis and performs trophic functions, including in the nervous system. The indicated growth factor affects the processes of development and migration of nerve cells, their survival.

The aim of the study - to evaluate changes in the expression of VEGF in the cerebral cortex of circulatory disturbances under conditions of preliminary sensitization by brain antigen and immunocorrection.

Results. Observations have shown that sensitization by brain antigen leads to expressive neurodegenerative changes in the sensorimotor cortex and a significant decrease in VEGF expression in neurons. An increase in neurodegenerative and destructive changes in the cerebral cortex and a more significant decrease in the expression of VEGF in neurons characterize embolism of blood vessels of the hemocamcirculatory bed on the background of previous sensitization. In this case, partial recovery after a circulatory disturbance against the background of sensitization occurs more slowly than when the latter do not perform. This can be considering as an immunosupressive suppression of compensatory and restorative processes induced by sensitization. The increase in the number of glial cells observed after the ischemic attack was accompanied by an increase in expression of VEGF.

Immunophane significantly reduces the severity of neurodegenerative changes and a decrease in the expression of VEGF caused by both impaired circulations in the cerebral cortex and sensitization. This can be due either to the direct influence of the immunophane, due to its antioxidant properties, and indirectly, due to the relative activation of T-regulatory cells that act as one of the neuroprotective factors that activated after ischemia.

Conclusions. Sensitization by brain antigen results in expressive neurodegenerative changes in the sensorimotor cortex and a decrease in VEGF expression in neurons.

Embolism of cerebral vessels against the background of previous sensitization, characterized by increased neurodegenerative and destructive changes, an express decrease in VEGF expression and a slowing down of the recovery processes in the cerebral cortex.

Immunophane significantly reduces the severity of neurodegenerative changes and a decrease in the expression of VEGF caused by both impaired circulations in cerebral cortex and sensitization.

KEY WORDS: brain ischemia; sensitization; VEGF; imunophane. 